Hodgkiss, W., Liston, J., Goodwin, T. W. \& Jamikorn, Malini (1954). J. gen. Microbiol. 11, 438-450.

\title{
The Isolation and Description of two Marine Micro-organisms with Special Reference to their Pigment Production
}

\author{
By W. HODGKISS AND J. LISTON \\ Department of Scientific and Industrial Research, Torry Research \\ Station, Aberdeen \\ AND T. W. GOODWIN AND MALINI JAMIKORN \\ Department of Biochemistry, The University of Liverpool
}

SUMMARY: Two coryneform organisms (A1032 and A 1062) isolated from the skin mucus of Arctic cod, are described in detail. Strain A1032 may be a new species; strain A 1062 is a strain of Corynebacterium erythrogenes.

Three carotenoid pigments, all with very similar absorption spectra, were found in both strains. Two of these pigments were identified as neoxanthin and sarcinaxanthin. The third pigment has not been described previously and has been named corynexanthin; it is characterized by an extremely high adsorptive power. The three pigments occur in different relative amounts in the two strains. Diphenylamine has no qualitative effect on the pigments produced, but does tend slightly to inhibit the amount produced.

Strain A 1062 on certain media (notably blood agar base, Oxoid), produces large amounts of coproporphyrin III and smaller amounts of pentacarboxy-, tricarboxy-, and dicarboxy-porphyrins. Strain A1032 does not produce porphyrins.

Most bacteria isolated from the skin slime of various marine teleost fish are Gram-negative rods (Shewan, 1949). Organisms of the genus Corynebacterium, however, form an important part of the flora of shark which inhabit Australian waters (Wood, 1950), and they have also been identified in the bacterial flora of cod (Gadus morrhuae, L.) caught off Bear Island (Shewan \& Hodgkiss, 1951). According to Jensen (1952) these corynebacteria should be placed in his section Corynebacterium sensu lato.

The first part of this paper contains a detailed description of two such strongly chromogenic coryneform organisms isolated during a survey of the normal bacterial flora of Arctic cod undertaken with a view to identifying organisms concerned in the spoilage of fish (Shewan \& Hodgkiss, unpublished observations). The second section describes the pigments elaborated by these bacteria.

A characteristic of marine bacteria is that a large proportion of them are coloured (ZoBell, 1946); for example, ZoBell \& Feltham (1934) examined several thousand colonies growing on agar inoculated with sea water or marine mud, and found that $69 \cdot 4 \%$ were chromogenic. Later ZoBell \& Upham (1944) described fully twenty coloured species. Many species of marine bacteria which spoil fish are also chromogenic; the considerable literature on this subject has been summarized by ZoBell (1946). In spite of the availability 
of considerable amounts of material, no investigations into the nature of the pigmentation of marine bacteria have been reported. There is one report of carotenoids in a halophilic, but not marine, member of the Thiorhodaceae, Chromatium okenii, which is reported to contain, apart from bacteriochlorophyll, the carotenoid $\alpha$-bacteriopurpurin (Lévy, Teissier \& Wurmser, 1925). This pigment is one of two ( $\alpha$ - and $\beta$-bacteriopurpurin) obtained by Molisch (1907) from Bacterium rubescens. $\alpha$-Bacteriopurpurin also occurs in Flavobacterium arborescens (Sobin \& Stahly, 1942), in Bacterium halobium (Lederer, 1938) and possibly in traces in Rhodospirillum rubrum (Goodwin \& Osman, 1954); it is possibly demethylated rhodoviolascin (spirilloxanthin) (Karrer \& Solmssen, 1935; Polgár, van Niel \& Zechmeister, 1944). Although the experimental information is not complete, it is almost certain that all the purple sulphur and non-sulphur bacteria contain carotenoids along with bacteriochlorophyll (see Goodwin, 1952 $a$, for full details).

Little is known about the general factors which control pigmentation in marine bacteria. ZoBell \& Upham (1944) found that pigmentation was increased when the bacteria were grown in sea water enriched with Bactotryptone, neopeptone and beef extract at a low temperature $\left(4^{\circ}\right)$. ZoBell (1946) also quoted unpublished work by Upham which indicated that infusions of fish, octopus, mussel and other marine animals stimulated pigment production.

With regard to pigments in non-marine coryneform organisms, previous early reports indicated that $\beta$-carotene and unidentified xanthophylls were present in Corynebacterium spp., including $C$. diphtheriae (Skinner \& Gunderson, 1932; Baumann, Steenbock, Ingraham \& Fred, 1933; Chargaff, 1933). Recently, Starr \& Saperstein (1953) showed that the plant pathogen C. poinsettiae produces spirilloxanthin and lycoxanthin when grown on thiamine-low medium, and lycoxanthin + cryptoxanthin, with only small amounts of spirilloxanthin, on a thiamine-rich medium.

\section{THE ORGANISMS}

The two organisms to be described (A 1032 and A 1062) were primary isolations from the skin slime of Gadus morrhuae on horse-heart infusion agar cultures incubated at $20^{\circ}$.

\section{Organism $A 1032$}

Morphology. On horse-heart infusion agar the cells are slender, straight rods measuring $c .0 \cdot 4 \mu . \times 2 \cdot 0-3.0 \mu$. and are usually very uniform in size. They are non-motile, Gram-positive, non-acid-fast and do not form spores. Angular and palisade arrangements of the cells occur.

Colony appearances. After 5 days of incubation on horse-heart infusion agar at $20^{\circ}$ colonies are circular, $1.5 \mathrm{~mm}$. in diameter, with an entire margin and a convex to pulvinate smooth surface. They are semi-translucent, lemonyellow in colour.

Growth in fluid media. At first a uniform turbidity is produced, growth then becomes flocculent and a yellow sediment is formed. Pellicle formation does not occur. 
Temperature range. The optimal temperature for growth is $20-25^{\circ}$. No growth occurs at $37^{\circ}$ or at $0^{\circ}$. Growth at $5^{\circ}$ is moderate.

Biochemical characteristics. Acid is produced rapidly from glucose and maltose, and slowly from sucrose and mannitol. Lactose and dulcitol are not fermented and starch is not hydrolysed. Gelatin and Loeffler's serum are not liquefied. Nitrate and trimethylamine oxide are not reduced. Ammonia is not produced from peptone or from urea. Indole, methyl-red and Voges-Proskauer tests are negative. Litmus milk shows no change after incubation for 6 weeks. Sodium alginate and cellulose are not attacked.

Classification. It is considered that this organism must be classified as a Corynebacterium sp. and in accordance with the recommendations of Jensen would be placed in his section 'Corynebacterium sensu lato'. It does not resemble any of the species listed in Bergey's Manual (1948), and on further investigation may prove to be a new species.

\section{Organism $A 1062$}

Morphology. On horse-heart infusion agar the cells are rods measuring c. $0 \cdot 6-0 \cdot 8 \mu . \times 4 \cdot 0-5 \cdot 0 \mu$. In fluid media the cells are often longer (up to $8 \cdot 0 \mu$.). They may be straight or slightly curved, sometimes having a very angular appearance; a characteristic feature is the uneven thickness of the cell. False branching and 'budding' occurs. The organisms are non-motile, Gram-positive, non-acid-fast, non-spore forming.

Colony appearances. After 5 days of incubation at $20^{\circ}$ on horse-heart infusion agar colonies are circular, 2.0-3.0 $\mathrm{mm}$. in diameter, with an entire margin and a smooth moist convex to pulvinate surface. They are opaque and lemon-yellow in colour. Older cultures show rough variants and have a dried matt surface. A characteristic feature is the production of a red fluorescent pigment which diffuses into the medium when the organism is grown on certain media (see next section).

Growth in fluid media. At first a uniform turbidity and a thick yellow pellicle is produced. Usually the pellicle disintegrates (upon being disturbed or under its own weight) and growth becomes flocculent with a yellow flocculent sediment.

Temperature range. The optimal temperature for growth is $20-25^{\circ}$; growth does not occur at $37^{\circ}$. At $0^{\circ}$ there is an appreciable growth after 7-10 days of incubation.

Biochemical activities. Glucose, lactose, sucrose, maltose, dulcitol and mannitol are not fermented and starch is not hydrolysed. Gelatin stabs show slow infundibuliform liquefaction, which later becomes stratiform. Loeffler's serum is not liquefied. Ammonia is produced from urea and from peptone. Nitrates are reduced to nitrites. Indole, methyl-red and Voges-Proskauer tests are negative and trimethylamine oxide is not reduced. Litmus milk becomes strongly alkaline and a clot forms. Sodium alginate and cellulose are not attacked.

Classification. This organism is considered to be a marine variant of Corynebacterium erythrogenes Kisskalt \& Berend, 1918 (Bacterium erythrogenes 


\section{Chromogenic marine bacteria}

Lehmann \& Neumann). It differs from the original description only in the size of the cells, and in the cultural conditions under which the red pigment is produced.

\section{THE PIGMENTS}

Methods

Cultures. The two coryneform organisms A 1032 and A 1062 were cultivated mainly on blood agar base at room temperature (about $15^{\circ}$ ), but a number of other standard media were also used. The Sarcina lutea culture used to produce reference carotenoids was a strain (21) kindly provided by Dr H. K. King. It was grown on nutrient broth at $37^{\circ}$.

\section{Extraction, separation and characterization of the pigments}

Carotenoid pigments. The bacterial cells were scraped off the agar and shaken with methanol on a warm water-bath $\left(50-60^{\circ}\right)$ for $2-3$ min.; this extracted almost all the pigment into the methanol, which was decanted after allowing the residue to settle. The residue was similarly extracted once with methanol, and to the combined extracts was added an equal volume of diethyl ether, followed by water until two layers were formed. The upper ethereal layer, containing all the pigment, was freed from methanol by washing 3 times with small volumes of water. The ether was removed in vacuo at room temperature and the residue dried by adding a few drops of absolute ethanol and then blowing dry with a stream of $\mathrm{N}_{2}$ on a warm water-bath. The dry residue was dissolved in a very small volume of diethyl ether which was then diluted with light petroleum (the fraction boiling between 40 and $60^{\circ}$ was used throughout this investigation) to make an appropriate volume $(5 \mathrm{ml}$.) for chromatography.

It is important to note that the procedure usually used for the preliminary extraction of carotenoids from micro-organisms (Garton, Goodwin \& Lijinsky, 1951; Goodwin, 1952 b) was not applicable in the case of these coryneform bacteria. The usual method involves grinding the cells to a fine dry powder with acid-washed silver sand and anhydrous $\mathrm{Na}_{2} \mathrm{SO}_{4}$ and then extracting the pigments with warm diethyl ether or acetone. With the coryneform bacteria, no solvent investigated would extract the pigments from the dry powder; even methanol containing $5 \%(\mathrm{v} / \mathrm{v})$ glacial acetic acid was ineffective. The reason for this is, as will be seen later, partly due to the very great adsorptive power of the constituent carotenoids which remained firmly attached to the solid $\mathrm{Na}_{2} \mathrm{SO}_{4}$; the failure to extract the pigments with methanol + acetic acid is, however, somewhat inexplicable. It is obviously important that the failure to extract pigments from a coloured $\mathrm{Na}_{2} \mathrm{SO}_{4}$-dried bacterial powder with the usual fat solvents should not be construed as indicating the absence of carotenoids until other extraction procedures have been examined.

Carotenoids from Sarcina lutea. The cells of $S$. lutea grown on nutrient broth were harvested by centrifugation, and the carotenoids extracted from the cell mass by the method just described for the coryneform organisms.

Porphyrins from organism $A$ 1062. The porphyrins which were excreted into the solid medium were extracted, after the removal of the bacteria, by warming 
the medium on a water-bath until just molten and then shaking it with diethyl ether containing $5 \%(\mathrm{v} / \mathrm{v})$ glacial acetic acid.

Separation and identification of carotenoids. The carotenoids were chromatographed using three types of adsorption columns: (a) Alumina (Grade 'O'; P. Spence and Co., Widnes) deactivated with methanol according to the method of Goodwin \& Srisukh (1949). (b) $\mathrm{CaCO}_{3}$ of analytical grade previously dried at $140^{\circ}$ for $2 \mathrm{hr}$. and kept in a desiccator until used. It is important to use analytical $\mathrm{CaCO}_{3}$ because the laboratory grade contains $\mathrm{Ca}(\mathrm{OH})_{2}$, which is much more adsorptive than $\mathrm{CaCO}_{3}$ (Lederer, 1952). (c) Powdered cellulose (Whatman, Standard Grade). The solvents used for elution of the pigments were light petroleum, diethyl ether and ethanol.

The absorption spectra measurements were carried out on either a Beckman photoelectric spectrophotometer (Model DU) or the corresponding Unicam instrument (SP 500).

Saponification of the lipid extracts was carried out according to the method of Goodwin \& Morton (1946). The phase tests on the pigments were carried out by shaking a light petroleum solution of the pigment with methanol containing $10 \%(\mathrm{v} / \mathrm{v})$ of water.

Identification of the porphyrins. The detailed examination of the porphyrins was kindly carried out by Prof. C. Rimington, F.R.S., after our preliminary examination of absorption spectra, fluorescence and behaviour on paper chromatography had demonstrated their presence.

Quantitative determination of the pigments. The amount of carotenoids present was determined assuming $E_{1 \mathrm{~cm} .}^{1 \%}\left(\lambda_{\max }\right)$ to be 2500 . The porphyrins were determined using the value $E_{1 \mathrm{~cm}}^{1 \%}(401 \mathrm{~m} \mu$.) 7400 , reported by Todd (1949) for coproporphyrin III.

\section{Results}

\section{Pigments of coryneform organism A 1032}

The carotenoid mixture, which the partition test showed to consist of xanthophylls containing at least two free hydroxyl groups, was first chromatographed on weakened alumina. The major part of the pigment was so tightly adsorbed that it was impossible to remove it from the adsorbent with any solvent. A small fraction (A) was eluted with ethanol. There was no sign of any colourless fluorescing polyenes such as phytofluene. On chromatography on either $\mathrm{CaCO}_{3}$ or powdered cellulose, three fractions were obtained as described in Table 1. The most interesting fact about these three fractions is that they differ only in adsorptive power, their absorption spectra being almost identical.

The possibility existed that the pigment of zone $\mathrm{C}$, being the most strongly absorbed, was the parent polyhydroxy compound and that the pigments of zones $\mathbf{A}$ and $\mathbf{B}$ were derivatives in which different numbers of hydroxyl groups had been esterified, for it is well known that xanthophylls can exist in nature in the esterified state (Goodwin, 1952a). This possibility was ruled out by saponifying a pigment extract and rechromatographing the resulting mixture. The separation obtained was qualitatively and quantitatively the 
same as before saponification, thus indicating that the zones $\mathbf{A}$ and $\mathbf{B}$ contained distinct pigments and not esters of pigment $\mathrm{C}$.

Table 1. The separation of the carotenoids of coryneform organism A 1032 on $\mathrm{CaCO}_{3}$ and on powdered cellulose

\begin{tabular}{|c|c|c|c|c|c|}
\hline Zone & Colour & $\begin{array}{l}\mathrm{CaCO}_{3} \\
\text { (solvent system } \\
\text { required to } \\
\text { remove from } \\
\text { column) }\end{array}$ & $\begin{array}{l}\text { Powdered cellulose } \\
\text { (solvent system } \\
\text { required to } \\
\text { remove from } \\
\text { column) }\end{array}$ & $\begin{array}{l}\text { Absorption } \\
\text { spectral } \\
\text { maxima in } \\
\text { ether }(\mathrm{m} \mu .)\end{array}$ & Identification \\
\hline $\mathbf{A}$ & $\begin{array}{r}\text { Greenish } \\
\text { yellow }\end{array}$ & Light petroleum & Light petroleum & $414,437,467$ & Neoxanthin \\
\hline $\mathbf{B}$ & $\begin{array}{r}\text { Greenish } \\
\text { yellow }\end{array}$ & $\begin{array}{l}\text { Light petroleum } \\
+15-20 \%(\mathrm{v} / \mathrm{v}) \\
\text { ether }\end{array}$ & $\begin{array}{l}\text { Light petroleum } \\
+5 \%(v / v) \\
\text { ether }\end{array}$ & $414,437,467$ & Sarcinaxanthin \\
\hline $\mathbf{C}$ & $\begin{array}{r}\text { Greenish } \\
\text { yellow }\end{array}$ & $\begin{array}{c}\text { Ether }+5 \% \\
\text { ethanol }\end{array}$ & Ether & $415,438,467$ & $\begin{array}{l}\text { New pigment } \\
\text { (corynexanthin) }\end{array}$ \\
\hline
\end{tabular}

Zone A (Table 1), which was the same as zone A obtained from alumina, had an absorption spectrum (both in position and shape) and adsorptive power almost identical with those of neoxanthin and was indistinguishable from a specimen of this pigment obtained from a number of algae (Goodwin \& Jamikorn, unpublished observations). Neoxanthin was first obtained in small amounts from leaves by Strain (1938).

The pigment of zone $B$ was provisionally identified as sarcinaxanthin. Consequently, the pigments of a strain of Sarcina lutea were examined. Chromatography on $\mathrm{CaCO}_{3}$ yielded essentially one pigment which was eluted with light petroleum containing 15-20\% (v/v) ether. Very small amounts of another pigment with the same absorption spectrum as the main fraction were removed with ether containing $5 \%$ ethanol; it was probably the same as pigment $\mathrm{C}$ in the coryneform organisms. No carotenes were observed. The main fraction which is undoubtedly sarcinaxanthin (Takeda \& Ohta, 1941; Sobin \& Stahly, 1942) had the same absorption spectrum as pigment B, and on carrying out a mixed chromatogram with pigment $B$ and sarcinaxanthin on $\mathrm{CaCO}_{3}$ no separation could be obtained. These observations, combined with the fact that no other carotenoids are known with the same absorption spectrum and the same adsorptive power (see Goodwin, 1952a), make it certain that pigment $\mathbf{B}$ is sarcinaxanthin.

Pigment $\mathrm{C}$ is entirely new, for no carotenoid is known with such very high adsorptive power; astaxanthin and fucoxanthin, which are bordering on the same degree of adsorptive power, have entirely different spectral and general properties (Karrer \& Jucker, 1950; Goodwin, 1952a). It is proposed to name this new carotenoid corynexanthin. The absorption spectrum of corynexanthin in various solvents is given in Fig. 1 , and the exact absorption maxima of neoxanthin, sarcinaxanthin and corynexanthin in various solvents in Table 2. It should be emphasized that, as the shapes of the spectra of these three pigments are almost identical, it is impossible to distinguish them solely by spectroscopic methods. The same three pigments were produced by coryneform organism A1032 on all the media examined. 
Pigments of coryneform organism A 1062

The presence of the same three carotenoid pigments obtained from organism A 1032 were demonstrated in organism $\mathbf{A 1 0 6 2}$ by using the same techniques. The relative amounts of the three pigments in the two organisms were deter-

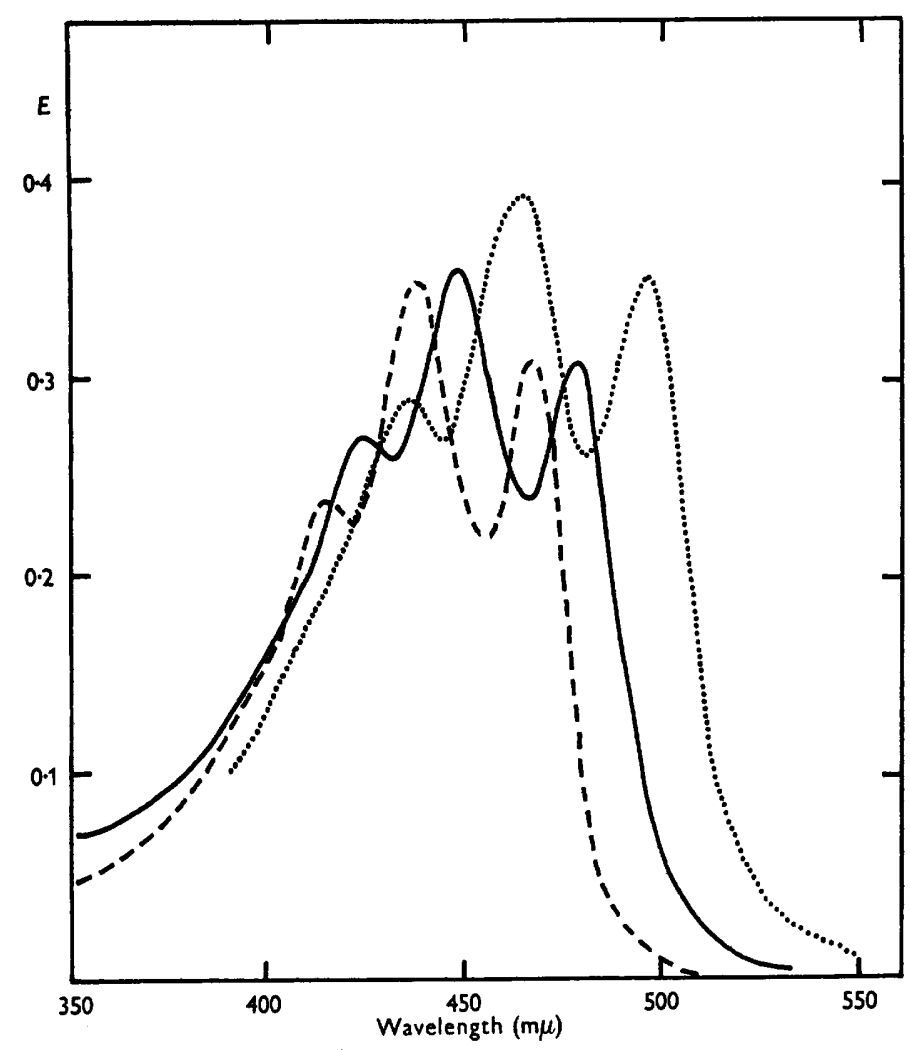

Fig. 1. The absorption spectrum of corynexanthin in various solvents. --- , diethylether; $\longrightarrow$, chloroform; $\cdots$, , carbon disulphide.

Table 2. The absorption spectral maxima $(m \mu$.) of the carotenoid pigments in the coryneform organisms $A 1032$ and $A 1062$ in various solvents

\begin{tabular}{|c|c|c|c|c|}
\hline & \multicolumn{4}{|c|}{ Solvent } \\
\hline & Diethyl ether & Ethanol & Chloroform & Carbon disulphide \\
\hline & \multicolumn{4}{|c|}{ Spectral maxima $(\mathrm{m} \mu)}$. \\
\hline Neoxanthin & $414,437,467$ & $415,437,467$ & $422,447,478$ & $433,458,489$ \\
\hline Sarcinaxanthin & $414,437,467$ & $417,439,469$ & $422,448,476$ & $436,467,497$ \\
\hline Corynexanthin & $415,438,467$ & $416,440,469$ & $423,447,478$ & $435,466,497$ \\
\hline
\end{tabular}

mined; Table 3 shows the result of a typical experiment. It will be seen that whilst neoxanthin existed to the same extent in both strains there was a considerable difference in regard to sarcinaxanthin and corynexanthin. Sarcina- 


\section{Chromogenic marine bacteria}

xanthin was the major component in organism A1032 and corynexanthin in organism A 1062 (Table 3). The same relative amounts of carotenoids were always produced on the different media tested.

Table 3. The relative amounts of the carotenoid pigments in the coryneform organisms $A 1032$ and $A 1062$

\begin{tabular}{|c|c|c|}
\hline \multirow[b]{2}{*}{ Pigment } & \multicolumn{2}{|c|}{ Coryneform organism } \\
\hline & A 1032 & A 1062 \\
\hline & \multicolumn{2}{|c|}{$\%$ of total pigments present } \\
\hline Neoxanthin & $21 \cdot 3$ & $26 \cdot 3$ \\
\hline Sarcinaxanthin & $73 \cdot 3$ & $23 \cdot 5$ \\
\hline Corynexanthin & $5 \cdot 4$ & $50 \cdot 2$ \\
\hline
\end{tabular}

The porphyrins produced by organism A 1062

It was found that organism A 1062 when grown on Lab-Lemco agar (Oxoid) or blood agar base (Oxoid) formed a brownish red pigment in the medium. This pigment could be extracted from the medium, after growth, by diethyl ether containing $5 \%(\mathrm{v} / \mathrm{v})$ glacial acetic acid. It fluoresced bright pinkish red in ultraviolet light and exhibited an absorption spectrum with the position and shape of bands corresponding to coproporphyrin III $\left(\lambda_{\max }, 624,595,571\right.$, 529, 497, 389, 271 $\mathrm{m} \mu$. in acid ethanol; compare 623, 596, 531 and $497 \mathrm{~m} \mu$. recorded by Lemberg \& Legge, 1949). Paper chromatography according to the method of Nicholas \& Comfort (1949) indicated one major pigment with approximately the same $R_{\boldsymbol{F}}$ value as coproporphyrin III; a small amount of brown material was also present. Further examination of this pigment was carried out by Prof. Rimington and his colleagues who reported: 'Chromatography by Eriksen's method in 2:6-lutidine showed that it was mainly coproporphyrin III, but it also contained some pentacarboxylic porphyrin and some tricarboxylic porphyrin, both giving a fairly strong spot. Examined by the Chu method, the pigment appeared to move as coproporphyrin III. It would appear therefore that the pigment produced is, in fact, mainly coproporphyrin III.'

Examination of porphyrin formation on various laboratory media by organism A 1062 showed that it occurred only with growth on blood agar base (Oxoid) and Lab-Lemco (Oxoid). No formation of porphyrin was observed on the following media: agar (British Drug Houses Ltd., or Oxoid) + peptone (Evans or Oxoid); agar + peptone + yeast extract; nutrient broth (Oxoid); nutrient broth + sterile blood (Evans); nutrient broth + yeast extract, although growth was good on all these media except on agar + peptone + yeast extract. Although no porphyrin was formed in the medium containing blood, the haem appeared to be metabolized because the medium lost its red colour soon after inoculation with the bacteria. When grown on blood agar basal medium made in our laboratory from the commercially available constituents, Lab-Lemco, peptone and agar (all Oxoid), no porphyrin was produced, although the bacterium grew normally. Through the kindness of Messrs Oxo Ltd. we were 
able to examine the crude meat extract, used in the manufacture of blood agar base, which is purified before being marketed as Lab-Lemco. Using this with Oxoid peptone and agar, a blood agar base was produced on which organism A 1062 did produce porphyrin, although in smaller amounts than when grown on the commercial blood agar base. The replacement of Oxoid peptone by the peptone syrup used in the production of commercial blood agar base had no stimulatory effect on porphyrin production. Porphyrin was also synthesized in the medium used to test for ability of the organism to reduce trimethylamine oxide (Wood \& Baird, 1943). No porphyrin was formed following the removal of trimethylamine oxide from the medium or its replacement by betaine, dimethylamine or trimethylamine.

Organism A1032 produced no porphyrin on any medium examined.

\section{Quantitative experiments on pigment production}

The pattern of pigment synthesis by organism A 1062 was investigated and the results are shown in Table 4. The production of carotenoids and of porphyrin was maximal between the fourth and sixth days of incubation. The porphyrin disappeared quite quickly from older cultures, the carotenoids much less quickly. Some of both kinds of pigment, however, remained even in very old cultures which were still slightly yellow, and in the medium which fluoresced slightly pink.

Table 4. Carotenoid and porphyrin formation by organism $A 1062$ at various stages of growith

Amounts produced on $10 \mathrm{ml}$. blood agar medium. Incubation temperature $15^{\circ}$. Values are mean of three tubes.

\begin{tabular}{|c|c|c|c|}
\hline \multicolumn{4}{|c|}{ Media } \\
\hline $\begin{array}{l}\text { Blood agar } \\
\text { base }\end{array}$ & $\begin{array}{c}\text { Blood agar base } \\
\text { +diphenylamine } \\
(\mathbf{1} / \mathbf{3 5 , 0 0 0 )}\end{array}$ & $\begin{array}{c}\text { Blood agar } \\
\text { base }\end{array}$ & $\begin{array}{c}\text { Blood agar base } \\
+ \text { diphenylamine } \\
(\mathbf{1} / \mathbf{3 5}, 000)\end{array}$ \\
\hline
\end{tabular}

\begin{tabular}{|c|c|c|c|c|}
\hline \multirow{2}{*}{$\begin{array}{c}\text { Age of } \\
\text { culture } \\
\text { (days) } \\
2\end{array}$} & \multicolumn{2}{|c|}{$\begin{array}{l}\text { Total carotenoids } \\
\quad(\mu \mathrm{g} .)\end{array}$} & \multicolumn{2}{|c|}{$\begin{array}{l}\text { Porphyrins } \\
(\mu \mathrm{g} .)\end{array}$} \\
\hline & 0.9 & - & 5.0 & - \\
\hline 4 & $2 \cdot 4$ & $0 \cdot 4$ & $15 \cdot 7$ & $3 \cdot 1$ \\
\hline 6 & $2 \cdot 2$ & - & $15 \cdot 9$ & - \\
\hline 8 & $2 \cdot 1$ & $1 \cdot 6$ & 8.5 & $10 \cdot 2$ \\
\hline 10 & 1.9 & - & $5 \cdot 5$ & - \\
\hline 12 & 1.8 & 1.4 & 4.9 & $10 \cdot 1$ \\
\hline
\end{tabular}

The action of diphenylamine

Diphenylamine is a specific inhibitor of carotenogenesis in Mycobacterium phlei (Turian, 1950) and Phycomyces blakesleeanus (Goodwin, 1952b). In each case, although the synthesis of coloured polyenes (carotenoids) is inhibited, there is a concomitant increase in the synthesis of related colourless polyenes such as phytoene, phytofluene, etc. The effect of diphenylamine on carotenoid production by organism A 1062 is shown in Table 4, which indicates that the 
amount produced/tube was decreased and that this effect was also apparent on the synthesis of porphyrin. From the appearance of 8-day and older cultures, when growth covered the agar slopes, this effect did not appear to be due to an inhibition of growth. Growth rate was, however, considerably decreased in the presence of diphenylamine; there was not sufficient growth to carry out an analysis after 2 days incubation and only just sufficient at 4 days. More important from the point of view of carotenoid synthesis is the fact that chromatographic analysis of the carotenoids extracted from diphenylamine-containing cultures demonstrated the presence of the three normal pigments only; there was no trace of the more saturated polyenes which one might have expected to have been produced under the influence of diphenylamine. Diphenylamine-containing cultures of organism $\mathbf{A} 1032$ behaved in the same way as the corresponding cultures of strain A1062.

\section{DISCUSSION}

\section{The carotenoids}

The fact that the three xanthophylls present in organisms A 1032 and A 1062 have almost identical absorption spectra but different absorptive powers, indicate that they must contain the same chromophoric grouping but different numbers of polar groupings (hydroxyl, keto, epoxy, or carboxyl). It is possible from the information available to draw some conclusions about the structure of these pigments, especially in the sense of eliminating unlikely structures. Assuming the pigments are $\mathrm{C}_{40}$ carotenoids (as are almost all naturally occurring carotenoids) the following can be ruled out: $(a)$ keto-groups, because the characteristic property of a ketonic carotenoid, e.g. astaxanthin or echinenone, is its single banded spectrum (Goodwin \& Srisukh, 1949; Goodwin \& Taha, 1950); (b) carboxyl-groups, because the pigments show no acidic properties; $(c)$ the 5, 8-epoxy-derivatives of $\alpha$ and $\beta$ carotenes because their spectral maxima are at lower wavelengths than are those of the present pigments (see Goodwin, 1952 $a$; Karrer \& Jucker, 1950).

As far as present knowledge goes, only two possibilities remain: (i) the pigments are polyhydroxy-partly hydrogenated derivatives of $\alpha-, \beta$ - or $\gamma$ carotenes or lycopene; or (ii) hydroxy derivatives of 5:8-epoxy- $\gamma$-carotene.

With regard to possibility (i), the pigments must contain three or more hydroxyl groups because they are very much more strongly absorbed than the dihydroxy pigments lutein and zeaxanthin. They must be more saturated than the carotenes mentioned because their absorption spectral maxima are at lower wavelengths. The strong definition of the absorption spectra of the pigments suggests that they are derivatives of lycopene. If this be so, then the difference of 33-35 $\mathrm{m} \mu$. between the positions of the absorption maxima of lycopene and those of the present pigments indicates that they would be tetrahydrolycopene derivatives. This would make them derivatives of the known pigment neurosporene (Haxo, 1949). The absorption maxima of neurosporene agree almost exactly with those of the present pigments, but the shape of its curve is somewhat different. Although the definition of the curves of 
$\alpha$ - and $\beta$-carotene is much less than that of the present pigments, they cannot be ruled out as parents of these pigments because it is not known what the effect of partial saturation is on the shape of the $\alpha$ - and $\beta$-carotene curves.

With regard to possibility (ii): 5:8-epoxy- $\gamma$-carotene has not yet been described as a natural product, but from the known properties of $5: 8$-epoxides (Karrer \& Jucker, 1950), the absorption spectrum of such a compound would be very similar to that of the coryneform pigments although the shape might be different. A further point against a 5:8-epoxy structure is that these compounds give a characteristic blue coloration with ethereal $\mathrm{HCl}$; the coryneform pigments give no such colour.

The failure of diphenylamine to have any effect on the types of polyene synthesized by these coryneform bacteria is further demonstration that the mechanism of carotenoid synthesis in different organisms must vary considerably. The action of diphenylamine on Euglena gracilis v. bacillaris (Goodwin \& Jamikorn, unpublished observations) and Rhodopseudomonas spheroides (Goodwin, Land \& Osman, unpublished observations), is similar to that on the coryneform pigments, but in Mycobacterium phlei (Turian, 1950; Turian \& Haxo, 1952; Goodwin \& Jamikorn, unpublished observations), Phycomyces blakesleeanus (Goodwin, 1952b; Goodwin, Jamikorn \& Willmer, 1952) and Rhodospirillum rubrum (Goodwin \& Osman, 1954), the synthesis of the carotenoids is inhibited whilst that of the colourless polyenes is stimulated.

\section{Porphyrin synthesis by organism A1062}

It is important to emphasize the very limited conditions under which porphyrin formation occurred with this organism. It occurred maximally only on commercially prepared Oxoid Lab-Lemco agar or blood agar base. These media, when prepared in the laboratory from commercially available components permitted porphyrin formation only when the crude meat extract, normally incorporated into the commercial complete media, was used instead of the purified Lab-Lemco. When this purified Lab-Lemco was used porphyrin formation did not occur. It must be concluded that not only does the purification of the meat extract remove a factor necessary for porphyrin formation but that the dehydration of the combined crude meat extract peptone syrup agar mixture to produce the commercial blood agar base, liberates or produces more of this unknown factor, for porphyrin formation was greatest on the commercially produced preparations. Whether this factor is related to trimethylamine oxide, which also stimulates some porphyrin formation, remains for further investigations to decide.

The first part of this paper was carried out as part of a programme of the Food Investigation Organization of the Department of Scientific and Industrial Research. We are extremely grateful to: Prof. C. Rimington, F.R.S., for examining the porphyrin mixtures; Dr H. G. Rees (Chief Chemist, Oxo Ltd) for information concerning the manufacture of bacteriological media and for samples of crude meat extract and peptone syrup; the Medical Research Council for a grant (to T.W.G.) towards laboratory expenses. 


\section{REFERENCES}

Bauman, C. A., Steenbock, H., Ingraham, M. A. \& Fred, E. B. (1933). Fat soluble vitamins. xxxviii. Micro-organisms and the synthesis of carotene and vitamin A. J. biol. Chem. 103, 339.

Bergey's Manual of Determinative Bacteriology (1948). 6th ed. Edited by Breed, R. S., Murray, E. G. D. \& Hitchens, A. P. London: Baillière, Tindall and Co.

Chargaff, E. (1933). Über das Fett und das Phosphatid der Diphtheriebakterien. Hoppe-Seyl. Z. 218, 223.

Garton, G. A., Goodwin, T. W. \& Lijinsky, W. (1951). General conditions governing $\beta$-carotene synthesis by the fungus Phycomyces blakesleeanus. Biochem. J. 48, 151.

Goodwin, T. W. (1952a). The Comparative Biochemistry of the Carotenoids. London: Chapman and Hall.

Goodwin, T. W. $(1952 b)$. Identification of the minor polyene components of the fungus Phycomyces blakesleeanus and a study of their synthesis under various conditions. Biochem. J. 50, 550 .

Goodwin, T. W., JAMikorn, M. \& Willmer, J. S. (1952). The mode of action of diphenylamine in inhibiting carotenogenesis in Phycomyces blakesleeanus. Biochem. J. 53, 531.

Goodwin, T. W. \& Morton, R. A. (1946). The determination of carotene and vitamin $\mathrm{A}$ in butter and margarine. Analyst, 71, 15.

Goodwin, T. W. \& Osman, H. G. (1954). Spirilloxanthin synthesis in washed suspension of Rhodospirillum rubrum. Biochem J. 56, 222.

Goodwin, T. W. \& SRIsukr, S. (1949). The Carotenoids of the integument of two locust species, Locusta migratoria migratorioides and Schistocerca gregaria. Biochem. J. 45, 263.

Goodwin, T. W. \& TAHA, M. M. (1950). The carotenoids of the gonads of the limpets Patella vulgata and Patella depressa. Biochem. J. 47, 244.

Haxo, F. (1949). Studies on the carotenoid pigments of Neurospora. 1. Composition of the pigment. Arch. Biochem. 20, 400.

Jensen, H. L. (1952). The Coryneform Bacteria. Ann. Rev. Microbiol. 6, 77.

Karrer, P. \& Jucker, E. (1950). Carotenoids (Tr. E. A. Braude). London: Elsevier.

Karrer, P. \& Solmssen, U. (1935). Die Carotinoide der Purpurbakterien 1. Helv. chim. Acta, 18, 1306.

Kisskalt, K. \& Berend, E. (1918). Untersuchungen über die Diphtheroide (Corynebacterien). Zbl. Bakt. (1 Abt.), 81, 444.

Lederer, E. (1938). Sur les caroténoides des cryptogames. Bull. Soc. Chim. biol. 20,611 .

LEDERER, E. (1952). Sur les pigments naphtoquinoniques des épines et du test des oursins Paracentrotus lividus et Arbacia pustulosa. Biochem. biophys. Acta, 9, 92.

Lemberg, R. \& Legge, J. W. (1949). Hematin Compounds and Bile Pigments. New York: Interscience Publishers.

Lévy, R., Teissier, G. \& Wurmser, R. (1925). Études des pigments d'une bacteriacée. Ann. Physiol. Physicochim. 1, 298.

MoLisch, H. (1907). Die Purpurbacterien nach neuen Untersuchungen. Jena: Fischer.

Nicholas, R. E. H. \& Comfort, A. (1949). Acid soluble pigments of molluscan shells. 4. Identification of shell porphyrins with particular reference to conchoporphyrin (1949). Biochem. J. 45, 208.

Polgár, A., van Niel, C. B. \& Zechmeister, L. (1944). Studies on the pigments of the purple bacteria. II. A spectroscopic and stereochemical investigation of spirilloxanthin. Arch. Biochem. 5, 243.

Shewan, J. M. (1949). Some bacteriological aspects of handling, processing and distribution of fish. J. Roy. san. Inst. 69, 394. 
Shewan, J. M. \& Hodgkiss, W. (1951). Some aspects of the bacteriology of marine fish. Proc. Soc. appl. Bact. 14, vii.

Skinner, C. E. \& Gunderson, M. F. (1932). Production of vitamin A by a species of Corynebacterium. J. biol. Chem. 97, 53.

Sobin, B. \& Stahly, G. L. (1942). The isolation and absorption spectrum maxima of bacterial carotenoid pigments. J. Bact. 44, 254.

Starr, M. P. \& Saperstein, S. (1953). Thiamine and the carotenoid pigments of Corynebacterium poinsettiae. Arch. Biochem. Biophys. 43, 157.

StraIN, H. H. (1938). Leaf Xanthophylls. Washington: Carnegie Institute.

TAKeda, Y. \& OHTa, T. (1941). Ein neues bakterien Carotinoid, Sarcinaxanthin. Hoppe-Seyl. Z. 268, 1.

Todd, C. M. (1949). Occurrence of cytochrome and coproporphyrin in mycobacteria. Biochem. J. 45, 386.

Turian, G. (1950). Recherches sur la biosynthèse des caroténoides chez un bacille paratuberculeux. III. Inhibition de la pigmentation par la diphenylamine. Helv. chem. Acta, 33, 1303.

Turian, G. \& Haxo, F. (1952). Further use of diphenylamine for the study of carotenoid biosynthesis in Mycobacterium phlei. J. Bact. 63, 690.

Wood, A. J. \& Baird, Elizabeth, A. (1943). Reduction of trimethylamine by bacteria. I. The Enterobacteriaceae. J. Fish. Res. Bd Can. 6 (no. 2), 194-201.

Wood, E. J. F. (1950). The bacteriology of shark spoilage. Aust. J. Mar. Freshw. Res. $1,129$.

ZoBels, C. E. (1946). Marine Microbiology. Waltham, Mass. U.S.A.: Chronica Botanica.

ZoBeld, C. E. \& Feltham, C. B. (1934). Preliminary studies on the distribution and characteristics of marine bacteria. Bull. Scripps Instn Oceanogr. tech. 3, 279.

ZoBeLL, C. E. \& UpHaM, H. C. (1944). A list of marine bacteria including descriptions of sixty new species. Bull. Scripps Instn Oceanogr. non-tech. 5, 239.

(Received 14, June 1954) 